\title{
Rola fotografii w komunikowaniu politycznym na przykładzie „portretu podwójnego" Lecha i Marii Kaczyńskich
} W $\begin{gathered}\text { katastrofie lotniczej z } 10 \text { kwietnia } 2010 \text { r. zginęło } 96 \text { osób, m.in. } \\ \text { ostatni prezydent RP na uchodźstwie Ryszard Kaczorowski, wice- }\end{gathered}$ marszałkowie Sejmu i Senatu, dowódcy wszystkich rodzajów Sił Zbrojnych RP. Jednak uwaga mediów skupiła się na osobie prezydenta Rzeczypospolitej Polskiej Lecha Kaczyńskiego i jego małżonki. Jest to całkowicie zrozumiałe, zważywszy na rangę aktora politycznego. Jednocześnie trudno nie zauważyć, iż sposób funkcjonowania mediów w okresie żałoby narodowej odzwierciedla ich swoistą logikę. Mowa o logice spektaklu, logice emocjonalnego show bazującego na sprawdzonych schematach, formatach, mechanizmach, gatunkach wypowiedzi, środkach ekspresji; warto przy tym pamiętać, że wiele spośród nich stanowi adaptację rozwiązań utrwalonych w tradycji kultury.

Niniejszy artykuł jest nawiązaniem do rozważań Piotra Pawełczyka na temat roli rekwizytu w komunikowaniu politycznym ${ }^{1}$ i dotyczy sposobu wykorzystania wspólnej fotografii ${ }^{2}$ Lecha i Marii Kaczyńskich: a) w okresie żałoby narodowej; b) w kampanii prezydenckiej 2010; c) w kampanii parlamentarnej 2011. „Portret podwójny” małżonków Kaczyńskich stał się instrumentem komunikowania politycznego, służąc realizacji celów pewnych grup mediów oraz podmiotów polityki. Analiza ma na celu ustalenie okoliczności i zakresu wykorzystania fotografii Lecha i Marii Kaczyńskich, określenie roli, jaką wypełniał ten komunikat, gdy posługiwały się nim media drukowane oraz gdy czyniła to partia

1 P. Pawełczyk, Rola rekwizytu w komunikowaniu politycznym, w: E-wydawnictwo.eu. Portal publikacji naukowych, http://www.e-wydawnictwo.eu/Document/DocumentPreview/416, s. 173-183, dostęp: 25.05.2011.

2 W dalszej części artykuły nazywam ją ,portretem podwójnym”, analizując w perspektywie strukturalnej oraz funkcjonalnej. 
polityczna, a także wskazanie potencjalnego zysku nadawców z prezentacji wizerunków w przestrzeni publicznej.

\section{Okoliczności i sposoby wykorzystania wspólnej fotografii Lecha i Marii Kaczyńskich}

Okres żałoby narodowej zamknął się między datą katastrofy a dniem pogrzebu pary prezydenckiej (10-18 kwietnia 2010 r.). Niniejszy fragment jest próbą przypomnienia, jak wybrane segmenty polskiej prasy wizualizowały oba wydarzenia. Wybór prasy jako medium, którego przekazy posłużą egzemplifikacji pewnych zjawisk, nie jest przypadkowy. Zważywszy na obecne standardy techniczne, ale i na sposób zaspokajania potrzeb czytelniczych, poza przekazami językowymi drukowane gazety i czasopisma oferują liczne, coraz bardziej wyrafinowane pod względem formalnym, komunikaty ikoniczne. Wbrew opinii o kryzysie mediów drukowanych i rychłym końcu gazet, nadal cieszą się one sporym zainteresowaniem odbiorców. Z raportu Centrum Badania Opinii Społecznej wynika, że 63\% respondentów systematycznie zapoznawało się z tym, co na temat katastrofy pod Smoleńskiem i uroczystości pogrzebowych pisano $\mathrm{w}$ prasie. Jednocześnie niemal co trzeci badany kupił numer specjalny któregoś $\mathrm{z}$ dzienników lub tygodników poświęconych tylko tym wydarzeniom ${ }^{3}$. Stąd decyzja o analizie zawartości pism z wybranych segmentów.

W okresie żałoby narodowej na łamach tabloidów: „Faktu” i „Super Expressu”, przeważały fotografie kolorowe, spośród ofiar katastrofy smoleńskiej najczęściej portretowano Lecha i Marię Kaczyńskich (wspólne ujęcia). Część tytułów przynależących do segmentu kolorowej prasy kobiecej nie odnotowała katastrofy z 10 kwietnia 2010 r. i jej następstw, te natomiast, które postanowiły udźwignąć emocjonalny ciężar wydarzenia, decydowały się na częściowe tylko zagospodarowanie łamów motywami funeralnymi. Kilka analizowanych tytułów anonsowało tematykę smoleńskiej na okładce, poniższa tabela zawiera sprawozdanie $\mathrm{z}$ ich zawartości.

3 Polska i Polacy po katastrofie smoleńskiej, „Komunikat z Badań” BS/78/2010, www.cbos.pl, dostęp: 28.02.2011. 
Tabela 1

Sposób komponowania okladki wydania skorelowanego z katastrofą smoleńską - prasa kobieca

\begin{tabular}{||l|l||}
\hline \multicolumn{1}{|c|}{$\begin{array}{c}\text { Tytul pisma } \\
\text { i data publikacji }\end{array}$} & \multicolumn{1}{|c|}{ Treść i forma okładki } \\
\hline $\begin{array}{l}\text { „Życie na gorąco” } \\
15 \text { kwietnia } 2010 \text { r. } \\
\text { (nr 15) }\end{array}$ & $\begin{array}{l}\text { Mozaika obrazów o różnej wielkości, w centrum kompozycji czar- } \\
\text { no-biały „portret podwójny”. Fotografia Marii i Lecha Kaczyńskich } \\
\text { to wizualizacja sytuacji nieformalnej. Mniejsze, kolorowe kadry uka- } \\
\text { zują osobę zapalającą znicz; powązkowski pomnik katyński; ,gest } \\
\text { Putina”, tj. sytuację, kiedy premier Rosji współczująco obją Donalda } \\
\text { Tuska; urwany ogon TU-154 M z charakterystyczną szachownica (fo- } \\
\text { tografia Sławomira Wiśniewskiego). } \\
\text { Na tylnej okładce brak reklam, widnieje natomiast fotografia fotogra- } \\
\text { fii, czyli „portretu podwójnego” umieszczonego pośród kwiatów na } \\
\text { Krakowskim Przedmieściu. }\end{array}$ \\
\hline $\begin{array}{l}\text { „Na żywo” } \\
15 \text { kwietnia 2010 r. } \\
\text { (nr 15) }\end{array}$ & $\begin{array}{l}\text { Kompozycja dwudzielna, oś symetrycznego podziału pionowa. Obok } \\
\text { (plan średni) mamy fotografię (półzbliżenie) smutnej córki. Rodziców } \\
\text { sportretowano na tle samolotu. }\end{array}$ \\
\hline $\begin{array}{l}\text { Świat \& Ludzie” } \\
15 \text { kwietnia 2010 r. } \\
\text { (nr 15) }\end{array}$ & $\begin{array}{l}\text { Wypełniający całą kolumnę ,portret podwójny”, na którym Maria } \\
\text { i Lech Kaczyńscy przytulają się. }\end{array}$ \\
\hline
\end{tabular}

Źródło: Opracowanie własne.

Nie tylko na okładkach, także wewnątrz tygodników kolorowych wydanych po katastrofie smoleńskiej można było spotkać portrety prezydenta. Prezentując L. Kaczyńskiego w trakcie wykonywania obowiązków głowy państwa, przywoływano obrazy spotkań z kolejnymi papieżami, Janem Pawłem II i Benedyktem XVI. Prywatne życie L. Kaczyńskiego ilustrowano także za pomocą ujęć z bratem-bliźniakiem, matką, córką, najczęściej jednak z żoną. (Nierzadko współ-bohaterem tych „nieformalnych" kadrów stawał się prezydencki pies lub kot ${ }^{4}$ ).

Nie budzi zdziwienia fakt, że prasa kobieca z dużym natężeniem eksploatowała wizerunek L. Kaczyńskiego, złożył się na to nie tyle status aktora politycznego, ile potężny ładunek emocjonalny, który można było wydobyć z okoliczności śmierci pary prezydenckiej. Tematyce mortualnej towarzyszyła zwykle aktualizacja sentymentalnych klisz i quasiromantycznych motywów („,miłość aż po grób”, „nawet śmierć ich nie rozdzieliła”, „razem żyli i razem zginęli” itp.), historia związku Lecha i Marii Kaczyńskich wyczerpuje bowiem kulturowy wzorzec tzw. idealnej miłości.

4 Por. P. Pawełczyk, op. cit., s. 181. 
Niektóre tygodniki społeczno-kulturalne i społeczno-polityczne przedłożyły wizualizację symboliczną nad realistyczną. Ta ostatnia oznacza szeroko rozumiany paralelizm między tekstem dziennikarskim a zdjęciem, na fotografiach realistycznych ważne jest to, co one przedstawiają. Innymi słowy mówiąc, obraz duplikuje znaczenia produkowane werbalnie. Natomiast w wiadomości prasowej wizualizowanej symbolicznie tekst nie zawiera elementów pokazywanych na zdjęciu, a opis fotografii znajduje się tylko w podpisie. Ważniejsze są znaczenia konotowane, determinowane społecznie i kulturowo, pełniące w komunikacji funkcję symboli kolektywnych ${ }^{5}$.

Tej metaforycznej strategii komunikacyjnej wobec katastrofy i pogrzebu pary prezydenckiej dowodzą okładki wydań kilku pism z okresu 12-25 kwietnia 2010 r. Przykładowo, „Tygodnik Powszechny” z 18 kwietnia 2010 r. przedstawił na okładce obraz rozkołysanego Dzwonu Zygmunta, w kadrze umieszczając także postać dzwonnika. Zdjęcie było retuszowane, monochromatyczne i z założenia nieostre, dzięki czemu udało się wykreować „ruch” obiektu. Symboliczny, a zarazem minimalistyczny był pomysł graficzny „Przekroju”; w wydaniu z 13 kwietnia 2010 r. okładka pisma (przednia i tylna) została całkowicie pozbawiona obiektów i sylwetek ludzkich, a całą jej powierzchnię zadrukowano czarną farbą. Okładka „Przeglądu” z 18 kwietnia 2010 r. zawierała obraz płonącej świecy na czarnym tle. Jednak i w segmencie prasy opinii nie zabrakło periodyków, które eksponowały wizerunki ofiar (tab. 2).

Tabela 2

Sposób komponowania okładki wydania skorelowanego z katastrofą smoleńską - prasa opinii

\begin{tabular}{||l|l||}
\hline $\begin{array}{c}\text { Tytul pisma } \\
\text { i data publikacji }\end{array}$ & \multicolumn{1}{|c||}{ Treść i forma okładki } \\
\hline 1 & \multicolumn{1}{|c||}{2} \\
\hline $\begin{array}{l}\text { „Polityka” } \\
17 \text { kwietnia 2010 r. } \\
\text { (nr 16) }\end{array}$ & $\begin{array}{l}\text { Tableau skomponowane z 25 czarno-białych portretów ofiar katastro- } \\
\text { fy, wyłąznie osób powiązanych ze światem polityki. Usytuowane } \\
\text { centralnie fotografie Lecha i Marii Kaczyńskich obwiedziono } \\
\text { biało-czerwoną wstążką. Tylna okładka w kolorze czarnym, w cen- } \\
\text { trum kompozycji wizualny „cytat”, tj. kadr TVP Info przedstawiający } \\
\text { ujęcie Sławomira Wiśniewskiego. }\end{array}$ \\
\hline
\end{tabular}

5 Zob. T. Piekot, Dyskurs polskich wiadomości prasowych, Kraków 2006, s. $125-135$. 


\begin{tabular}{||l|l||}
\hline \multicolumn{1}{|c|}{1} & \multicolumn{1}{|c||}{2} \\
\hline $\begin{array}{l}\text { „Najwyższy Czas” } \\
17 \text { kwietnia 2010 r. } \\
\text { (nr 16) }\end{array}$ & $\begin{array}{l}\text { Plan średni, ,portret podwójny”, para prezydencka w sytuacji oficjal- } \\
\text { nej. Fotografia monochromatyczna. }\end{array}$ \\
\hline $\begin{array}{l}\text { „Wprost” } \\
\text { (n kwietnia 2010 r. } 17)\end{array}$ & $\begin{array}{l}\text { Fotografia fotografii: obraz barwnego „portretu podwójnego” wkom- } \\
\text { ponowanego w stosy kwiatów na Krakowskim Przedmieściu. Obraz } \\
\text { wyretuszowano, zmieniając naturalny kolor kwiatów na grafito- } \\
\text { wo-czarny. Monochromatyczna tylna okładka z wizualizacją „gestu } \\
\text { Putina” (plan średni, wielkość kolumny). }\end{array}$ \\
\hline
\end{tabular}

Źródło: Opracowanie własne.

Wizerunek uśmiechniętego L. Kaczyńskiego z małżonką u boku, przypomniany przez prasę i utrwalony w świadomości jej odbiorców, był wykorzystywany jeszcze kilkukrotnie, tym razem jednak przez środowisko polityczne zmarłego prezydenta. Gdy 26 kwietnia 2010 r. ogłoszono, że kandydatem Prawa i Sprawiedliwości w przyspieszonych wyborach prezydenckich będzie Jarosław Kaczyński, zaczęto wręczać „portret podwójny” osobom składającym podpis na listach poparcia. Czarno-białe fotografie pary prezydenckiej zawierające na odwrocie cytaty z wypowiedzi L. Kaczyńskiego ${ }^{6}$ (np. „Tylko Polska sprawiedliwa, uczciwa i solidarna może się rozwijać" z 2005 r.) rozdawano w wielu miejscach, m.in. w Gdańsku ${ }^{7}$, Opolu, Wrocławiu, Kartuzach ${ }^{8}$. Jak uzasadniał członek Forum Młodych PiS zbierający podpisy pod kandydaturą J. Kaczyńskiego na południu kraju, „Nie ma w tym chyba nic zdrożnego, biorą je tylko ci, którzy chcą. A chcieli praktycznie wszyscy, którzy podeszli wpisać swoje dane pod kandydatem PiS. Tylko kilka młodych osób z uśmiechem odmówiło"". Podobną interpretację zawiera wypowiedź przewodniczącej PiS w okręgu gdańskim, Hanny Foltyn-Kubickiej: „Materiały przyszły z centrali już parę dni temu. Głupio

6 Zob. M. Kozioł, PiS rozdaje zdjęcia pary prezydenckiej za podpis poparcia dla Jarosława, http://www.polskatimes.pl/stronaglowna/250077,pis-rozdaje-zdjecia-pary-prezydenckiej-za-podpis-poparcia,id,t.html, dostęp: 29.04.2010.

7 Zagłosuj na Kaczyńskiego - zdjęcie Lecha i Marii gratis, http://wiadomosci.wp.pl/kat,1023499,title,Zaglosuj-na-Kaczynskiego-zdjecie-Lecha-i-Marii-gratis,wid, 12212483, wiadomosc.html?ticaid=1d1d0, dostęp: 12.06.2011.

8 W. Drewka, PiS zbiera podpisy, rozdaje program $i$ żałobne zdjęcia, http://expresskaszubski.pl/aktualnosci/2010/04/pis-zbiera-podpisy-rozdaje-program-i-zdjecia, dostęp: 30.04.2010.

9 J. Pszon, PiS dostaje 100 podpisów na godzinę, http://opole.gazeta.pl/opo1e/1,35086,7826409,PiS_dostaje_100_podpisow_na_godzine.htm, dostęp: 28.04.2010. 
wyszło, że to się zbiegło ze zbieraniem podpisów, ale nie ja o tym decydowałam. Sama mam pamiątkę po Piłsudskim i rozumiem, że ludzie chętnie biorą te zdjęcia. Mają format pocztówkowy, można je gdzieś postawić czy schować w książce"10. Argumentacja, że fotografia nie była formą gratyfikacji za złożony podpis, a „,portrety podwójne” zostały przekazane przez centralę, powraca w wypowiedziach wszystkich działaczy PiS indagowanych przez dziennikarzy w związku z akcją.

Następnie fotografia małżonków Kaczyńskich trafiła na łamy gazety internetowej pt. „Polska jest najważniejsza”"11. Pismo mieszczące się $\mathrm{w}$ segmencie prasy partyjnej ${ }^{12}$, publikowane jednak w formacie PDF, funkcjonowało w ramach witryny http://jaroslawkaczynski.info. Na osobnych podstronach udostępniano: biografię kandydata, informacje o udzielonym mu poparciu, zarówno indywidualnym, jak i środowiskowym, aktualności, wreszcie dział Polska jest najważniejsza, w którym przedstawiono obszerny wybór „głosów ludu” (nagrań wideo i audio oraz wiadomości sms i e-maili z wyrazami sympatii dla kandydata PiS). Gazeta funkcjonowała na tym samym poziomie struktury serwisu co Informacje dla wyborców, Poparcie dla kandydata, Do pobrania, Przynieś babci dowód, Kampania bezpośrednia, Program oraz Głos Polaków.

Z krótkich form dziennikarskich najchętniej wykorzystywano w PJN notatkę, nieco rzadziej infografię oraz infografikę. Spośród infografii PJN, jako informacji wyrażanych lub ilustrowanych fotografia, zwraca uwagę analizowany w niniejszym artykule „portret podwójny”. Komponent tekstowy w infografii nie thumaczy odbiorcom, co widzą na fotografii, raczej wyjaśnia, dlaczego widzą dane zjawisko i co im się z tym obrazem powinno kojarzyć. Innymi słowy, tekst nie może opisywać fotografii, ma być jej uzupełnieniem. Czarno-biała fotografia pary prezydenckiej

10 K. Katka, Zdjęcie Lecha $i$ Marii za poparcie dla Jarosława, http://trojmiasto.gazeta.pl/trojmiasto/1,35612,7826606,Zdjecie_Lecha_i_Marii_za_poparcie_dla_Jaroslawa.html\#ixzz1ZNo8ZrrY, dostęp: 28.04.2010.

11 W dalszej części artykułu będę stosować zamiennie skrótowiec PJN.

12 Wyliczając techniki promocji politycznej, Małgorzata Janik-Wiszniowska wskazała na rolę prasy partyjnej: „Zdarza się często, że partie polityczne posiadają własną prasę, broszury, biuletyny kolportowane wewnątrz struktur, bądź nawet udostępniane szerszemu gronu odbiorców. Tego typu zabieg służy m.in. podtrzymaniu lojalności partyjnej i wzmocnieniu na rynku politycznym, np. lokalnym, poprzez pełnienie funkcji informacyjnych, propagandowych i stricte reklamowych". Zob. M. Wiszniowska-Janik, Promocja i reklama polityczna, w: Marketing polityczny w teorii i praktyce, red. A. W. Jabłoński, L. Sobkowiak, Wrocław 2009, s. 192. 
opatrzona została tekstem: „W intencji ofiar smoleńskiej katastrofy modlili się w czwartek parlamentarzyści i pracownicy Kancelarii Prezydenta. Po mszy świętej, o 8.41 - godzinie katastrofy - złożyli kwiaty pod Pałacem Prezydenckim, zapalili znicze oraz odmówili modlitwę"13.

Po raz kolejny, choć nie ostatni, partia PiS użyła wizerunku prezydenta i jego małżonki, emitując przed głównymi serwisami informacyjnymi spot Zastuguja na prawdę (29-31 lipca 2011 r.). Dwuminutowy materiał poświęcony pamięci Lecha i Marii Kaczyńskich zawierał liczne zdjęcia pary, zarówno prywatne, jak i te wykonane podczas spotkań ze światowymi liderami politycznymi. Obrazom towarzyszyły napisy:

- „Tylko jedna kobieta miała klucz do jego serca...”,

- „Tylko przy niej był bezpieczny”,

- „Razem służyli Polsce...”,

- „Chciał być z nią do końca życia”,

- „Połączyła ich miłość mocniejsza niż śmierć”

oraz komentarz z offu: „Byli odważni, choć wielu brakowało odwagi, byli honorowi wśród tych bez honoru, służyli Polsce, kiedy wielu służyło tylko sobie. Byli wierni zasadom, w świecie pełnym zdrady. Oni czekają na prawdę, jesteśmy im to winni”. Nadawcom spotu zależało na przypomnieniu, że zmarła tragicznie para prezydencka zawsze występowała w obronie najważniejszych wartości i do końca służyła ojczyźnie. Ponadto film miał wskazywać na znaczenie katastrofy smoleńskiej dla państwa polskiego ${ }^{14}$.

Następnie ,portret podwójny” został wykorzystany na inaugurację kampanii PiS do parlamentu (sierpień 2011 r.). Przedstawiono wówczas intertekstualny w zamyśle plakat wyborczy. Tło plakatu stanowią drzwi od lodówki w kolorze jasnobłękitnym ${ }^{15}$, na drzwiach natomiast przywieszone zostały: barwne zdjęcie pary prezydenckiej oraz samoprzylepne kartki post-it, tzw. przypominajki, zawierające postulaty z programu wyborczego partii J. Kaczyńskiego:

- „Uczciwy i skuteczny rząd zamiast korupcji władzy”,

13 PJN, nr 9, s. 1.

14 „Zastuguja na prawdę” - nowy spot PiS (wideo), http://www.marketing-news.pl/message.php?art=30535, dostęp: 29.07.2011.

15 Wedle innego wariantu graficznego - tablica korkowa. Zob. W. Wybranowski, Wraca lodówka PiS. Na plakatach, „Rzeczpospolita” 9.08.2011, http://www.rp.pl/ artykul/182403,699205-Powrot-lodowki-PiS-Na-plakatach-wyborczych-.html, dostęp: 12.09.2011. 
- „Jeden podręcznik zamiast kredytów na książki”,

- „Równe dopłaty dla rolników zamiast uległości wobec UE”,

- „Państwo przyjazne rodzinom zamiast eksperymentów obyczajowych",

- „Godna praca i płaca zamiast niepewności”,

- „Szpitale bez kolejek i dla wszystkich zamiast płatnej służby zdrowia" itd.

Jak wyjaśniał rzecznik PiS, nadawcy celowo nawiązali do spotu promującego partię w wyborach parlamentarnych 2005 r. (ilustrację procesu ubożenia obywateli, do jakiego doprowadziłyby rządy liberalnej konkurencji, stanowiły wówczas znikające z lodówki produkty żywnościowe). Jednocześnie wkomponowana pomiędzy żółte karteczki fotografia pary prezydenckiej miała przypominać, że sprawa katastrofy smoleńskiej nie została wyjaśniona. Kilka tysięcy sztuk tego komunikatu trafiło głównie do małych i średnich miast.

Barwny wariant „portretu podwójnego" trafił również do 30-sekundowego spotu promującego PiS, który stacje telewizyjne zaczęły emitować we wrześniu 2011 r. Portret Polaków przedstawia m.in. młode małżeństwo z dziećmi, naukowiec i mechanik, czyli osoby, które „boją się, że mogą coś stracić, które aspirują do klasy średniej"16. Fotografia małżonków Kaczyńskich pojawia się w 8 sekundzie filmu, a 2-sekundowe ujęcie bazuje na efekcie zmiany perspektywy.

\section{„Portret podwójny” - ilustracja, symbol, rzecz?}

Po 10 kwietnia 2010 r. wspólne ujęcia Lecha i Marii Kaczyńskich zaczęły funkcjonować w dwóch kontekstach komunikacyjnych. Początkowo zyskały status fotografii stricte prasowej ${ }^{17}$, ilustracji tekstów dziennikarskich tyczących katastrofy smoleńskiej, przebiegu żałoby narodowej czy pochówku pary prezydenckiej. Wystarczy jednak przeanalizować niektóre z tych fotografii (tu: obrazy obramowanych ,portretów podwójnych” w różnych aranżacjach, np. wśród kwiatów, w dłoniach

16 Słowa rzecznika PiS Adama Hofmana, za: Portret Lecha i Marii Kaczyńskich w spocie PiS (VIDEO), http://www.polskatimes.pl/fakty/448702,portret-lecha-i-marii-kaczynskich-w-spocie-pis-video,id,t.html, dostęp: 9.09.2011.

17 Zob. K. Wolny-Zmorzyński, Fotograficzne gatunki dziennikarskie, Warszawa 2007, s. 73. 
żałobników itp.), by zauważyć, że ilustracja - jako reprezentacja rzeczywistości - uległa urzeczowieniu, w dalszej kolejności przeistaczając się w symbol.

Przedstawionym powyżej sposobom wykorzystania wizerunków Lecha i Marii Kaczyńskich sprzyjają obecne w naszej kulturze rytuały i formy ekspresji, zarówno zwyczaj (zarazem sposób) wykonywania fotografii ślubnej, jak i tradycja portretu trumiennego czy epitafijnego ${ }^{18}$. Wizerunki małżonków na fotografiach ślubnych często się idealizuje, poddaje retuszowi, tak by emanowały szczęściem i radością ${ }^{19}$. Nieco inaczej przedstawia się sprawa wizerunku zmarłego, który starano się utrwalać od czasów starożytnych; w tym obszarze, jak pokazują badania kulturoznawców, tendencja do idealizowania postaci zmarłego wchodziła w konflikt z potrzebą dochowania wierności stanowi rzeczywistemu i nierzadko oddawała pole realizmowi ${ }^{20}$. Co jednak niezmiernie ważne, wszelkimi sposobami starano się uczcić i podtrzymać pamięć o zmarłym, m.in. eksponując jego podobizny utrwalane różnymi metodami i technikami (maski i figury z wosku, podobizny z papier-mâché, odlewy gipsowe, portrety malowane na blasze, fotografie nagrobkowe itp.). Jako nadawca pierwotny w procesie komunikowania politycznego gazety i czasopisma przedstawiły skonwencjonalizowany, zatem idealny portret małżonków Kaczyńskich, z drugiej strony - kierując się logiką pompa funebris - nie pozwalały nawet na chwilę zapomnieć o bohaterach smutnego ceremoniału. Jak zauważył P. Pawełczyk, rekwizyt wzmaga dramaturgię sytuacji, w której jest wykorzystywany, pozwala wywołać pożądane emocje i atmosferę na widowni ${ }^{21}$. Podobnie wyraził się Marian Golka, oceniając zjawisko z perspektywy socjologii kultury. Kultura masowa, stworzona w oparciu o ludyczne i hedonistyczne potrzeby odbiorców, przejawia tendencję do tego, by wszystkie jej treści i przekazy były atrakcyjnym widowiskiem. „Wydarzenia polityczne, gospodarcze, ale także wszelkie dramaty ludzkie, katastrofy, śmierć - są tak

18 J. Chrościcki, Pompa funebris. Z dziejów kultury staropolskiej, Warszawa 1974, s. 259-260.

19 Wzorem figuratywności dla tego typu obrazów może być dzieło Jana van Eycka z 1434 r. pt. Portret matżonków Arnolfini, http://www.nationalgallery.org.uk/paintings/jan-van-eyck-the-arnolfini-portrait, dostęp: 25.05.2011.

${ }^{20}$ Por. D. Freedberg, Potęga wizerunków. Studia z historii i teorii oddziatywania, tłum. E. Klekot, Kraków 2005, s. 219.

21 P. Pawełczyk, op. cit., s. 174. 
prezentowane, aby nie tylko przyciagały uwagę, ale były na swój sposób atrakcyjne i pożądane" ${ }^{, 22}$.

Oderwany od pierwotnej sytuacji komunikacyjnej, wyjęty z kontekstu prasowego ,portret podwójny” udało się zaadaptować do kolejnych procesów komunikowania politycznego. Tym razem jednak nadawcą prymarnym stawała się konkretna partia, której działania starannie zaprojektowano (podczas gdy media reagujące na katastrofę lotniczą, zatem na wydarzenie niespodziewane, uruchomiły szereg mechanizmów w sposób nie do końca uświadomiony). W demokracji rekwizyty wykorzystuje się dla uwiarygodnienia przekazu, w celu podparcia go zmaterializowanymi dowodami, pobudzenia prostych skojarzeń i wyzwalania emocji ${ }^{23}$. Takim też celom służy „,portret podwójny” od etapu kampanii prezydenckiej 2010. Ma przypominać o wzruszeniach związanych z żałobą narodową, o pozytywnych cechach L. Kaczyńskiego (w których blasku grzeje się poniekąd także brat bliźniak). Wspólna fotografia pary prezydenckiej początkowo ogrywała rolę ilustracji, by z biegiem czasu stać się symbolicznym obrazem lojalności, czułości, wierności, zaangażowania, partnerstwa, miłości itd. Sztab PiS umiejętnie zaimplementował do własnych spotów telewizyjnych schemat narracyjny, jaki uobecnił się w prasie kolorowej; mowa o wykorzystywaniu dramatu małżonków Kaczyńskich - pary idealnej - do przedstawienia tematu katastrofy smoleńskiej w ogóle. Świadczy o tym warstwa językowa spotów promujących PiS w wyborach parlamentarnych 2011 r. „Portret podwójny” to także element przyciagający uwagę, nie tylko mediów: na obrazach funkcjonujących w przestrzeni publicznej po 10 kwietnia 2010 r. widnieją sympatyczni, uśmiechnięci ludzie, ich wizerunek ma moc magnetyzującą ${ }^{24}$. Niekorzystny wizerunek L. Kaczyńskiego został wyparty z pamięci zbiorowej w sposób, wydaje się, nieodwracalny. Akt wręczania wspólnej fotografii małżonków Kaczyńskich w zamian za udzielenie poparcia kandydatowi PiS przypomina marketingową technikę darmowej próbki, której otrzymanie obliguje do wzajemności ${ }^{25}$. Żona jako „rekwizyt życia

22 M. Golka, Socjologia kultury, Warszawa 2007, s. 154.

23 P. Pawełczyk, op. cit., s. 175.

24 Por. W. Cwalina, A. Falkowski, Marketing psychologiczny. Perspektywa psychologiczna, Gdańsk 2006, s. 178: „Umiejętność wzbudzania sympatii wydaje się cechą leżącą u podstaw wszystkich pozytywnych relacji społecznych”.

25 Por. R. Cialdini, Wywieranie wplywu na ludzi. Teoria i praktyka, Gdańsk 2004, s. 41. 
codziennego",26 dowodzący udanego życia rodzinnego i ocieplający wizerunek polityka to zjawisko stosunkowo obszernie zanalizowane w piśmiennictwie naukowym z zakresu komunikowania i marketingu politycznego ${ }^{27}$. Maria Kaczyńska wypełniała znakomicie tę funkcję przed 10 kwietnia 2010 r., jednak sposób portretowania prezydenta L. Kaczyńskiego po katastrofie pozwala skonstatować, iż przynajmniej pod względem wizerunkowym stracił on status autonomicznego aktora politycznego - stał się połową duetu małżeńskiego.

\section{Ocieplanie wizerunku Lecha Kaczyńskiego post mortem}

W okresie żałoby doniesienia mediów na temat aktorów politycznych miały bezwarunkowo pozytywny ton, czego ewidentny dowód stanowią portrety uśmiechniętego, pogodnego, korzystnie wyglądającego L. Kaczyńskiego. Przed 10 kwietnia 2010 r. prezydent nie mógł liczyć na podobny sposób wizualizowania ${ }^{28}$. Przeciwnie, jak stwierdził jeden z urzędników głowy państwa, media III Rzeczypospolitej uczestniczyły w ,przemyśle pogardy”. Miał on doprowadzić do wykreowania karykaturalnego wizerunku L. Kaczyńskiego, gdy ten jeszcze żył i pełnił eksponowane funkcje publiczne ${ }^{29}$. Wedle zwolenników zmarłego tragicznie prezydenta, intencjonalne przemilczenia mediów obejmowały jego zalety, zasługi i przejawy politycznej skuteczności, a powodowane były nienawiścią: „Lech Kaczyński ze strony największych mediów mógł liczyć wyłącznie na złą wolę. Wybrany przez większość narodu, nie podobał się właścicielom ośrodków medialnej propagandy"30.

„Zasługą” mediów mainstreamu mógł być społeczny odbiór L. Kaczyńskiego u schyłku kadencji. Jak wynika z badań CBOS, w styczniu

26 P. Pawełczyk, op. cit., s. 180.

27 Z najnowszych prac na ten temat można wskazać: A. Leszczuk-Fiedziukiewicz, Strategie ocieplania i kontrolowania wizerunku polityka na przykładzie prezydenckiej kampanii wyborczej 2010 r., „Studia Politologiczne” 2011, vol. 19, s. 142-178.

28 Por. J. Paradowska, Imperator $i$ jego żolnierze, „Polityka” 2009, nr 17 (25.04.2009.), s. 14. Okładka wspomnianego numeru to fotomontaż, Lech Kaczyński został w nim wystylizowany na rzymskiego cesarza.

${ }^{29}$ Jacek Sasin dla „Naszego Dziennika”, http:/www.kppis.pl/wybralismy_dla_was,356.html, dostęp: 12.10.2010.

$3 \overline{0}$ J. Pietrzak, Byt prezydentem dumnej Polski, w: Lech Kaczyński. Portret, zebrał i oprac. M. Karnowski, Kraków 2010, s. 267. 
2010 źle postrzegało działania prezydenta $58 \%$ pytanych, w lutym $62 \%$, $\mathrm{w}$ marcu natomiast $58 \%{ }^{31}$. Sondaż przeprowadzony na miesiąc przed katastrofą ukazuje L. Kaczyńskiego w niekorzystnym świetle, jako polityka niecieszącego się zbytnim poparciem obywateli, wobec którego żywi się głównie nieufność ${ }^{32}$.

Zmiana nastawienia do prezydenta ma związek z zasadą „o zmarłym (mówić) dobrze lub wcale..." (łac. de mortuis aut bene aut nihil), którą w sposobie prezentacji zmarłych zastosowały polskie media tradycyjne. W wyniku katastrofy doszło do emocjonalnej „dewastacji” polskiego społeczeństwa, więc z szacunku dla kulturowych rytów media przystosowały przekaz, także ten wizualny, do potrzeb i możliwości percepcyjnych odbiorców. Ponadto gazety sensacyjne oraz kolorowe czasopisma dla kobiet wykorzystały dramat małżonków Kaczyńskich dla uruchomienia mechanizmów fundamentalnych dla tego typu prasy.

Zgon w nadzwyczajnych okolicznościach (np. skutek wyniszczającej choroby, wypadku, katastrofy) czy spektakularny pochówek dają prasie asumpt do wykreowania pośmiertnego wizerunku polityka niepokrywającego się z portretem nakreślonym wcześniej. Z reguły śmierć nagła i niespodziewana lub też okupiona cierpieniem, bólem zyskuje wymiar uświęcający, uwznioślający; takiego efektu oddziaływania nie zapewnia, jak się wydaje, śmierć naturalna polityka, dowodzą tego reakcje mediów na zgon np. Krzysztofa Skubiszewskiego czy Edwarda Gierka. Poza tym, że polska prasa uświęciła ofiary katastrofy smoleńskiej, to wyeksponowała jednocześnie ich prywatny wymiar (,zwykły człowiek”). Media kreowały klimat bliskości z aktorami politycznymi, którzy zginęli pod Smoleńskiem, ukazując prywatne, często bardzo osobiste $\mathrm{w}$ tonie, fotografie $\mathrm{z}$ domowych archiwów.

„Katastrofa smoleńska istotnie wpłynęła na jego [L. Kaczyńskiego - przyp. M.M.] wizerunek w mediach, który dosyć wyraźnie przełożył się na społeczne opinie. Coraz częściej pojawiały się słowa uznania dla jego prezydentury oraz uwagi o niedocenianiu go za życia. Wypowiadano się o nim jako o człowieku i polityku, dostrzegając głównie mocne strony jego prezydentury, a zapominając o słabych"33. Fotografia małżon-

31 Badania opinii publicznej opublikowane $\mathrm{w}$ dziale Raporty $z$ badań, www.cbos.pl, dostęp: 20.10.2010.

32 Zob. Ocena prezydenta Lecha Kaczyńskiego, „Komunikat z Badań” BS/82/2010, www.cbos.pl, dostęp: 20.02.2011.

33 Ocena prezydenta Lecha Kaczyńskiego... 
ków Kaczyńskich stała się zatem jednym z mechanizmów kreowania nowego wizerunku ${ }^{34}$ prezydenta, swoistego pośmiertnego „rebrandin$\mathrm{gu}^{\prime 35}$. Poza efektem przełomu wizerunkowego PiS dysponowało „wartością dodaną" w postaci sympatii przeważającej części mediów i zaufania społecznego, jakim M. Kaczyńska - inaczej niż jej małżonek - cieszyła się przed i po 10 kwietnia 2010 r. „Portret podwójny”, multiplikowany przez tytuły prasowe w okresie żałoby narodowej, po jej zakończeniu stał się wykładnią zdublowanego pozytywnego stosunku Polaków do określonego środowiska politycznego. Nic zatem dziwnego, że PiS, które w komunikatach werbalnych podkreślało wartość „testamentu L. Kaczyńskiego", siebie stawiając w roli depozytariuszy jego postanowień, wykorzystało wielokrotnie wspólną fotografię (i przy okazji biografię) pary prezydenckiej.

\section{The role of photography in political communication based on the example of a 'double portrait' of Lech and Maria Kaczyński}

\section{Summary}

The catastrophe in Smoleńsk has significantly affected the image of Lech Kaczyński presented in the media, which has quite clearly translated into social opinions. Words of praise for his presidency and remarks that he had been underestimated became increasingly frequent. The picture of Mr and Mrs Kaczyński therefore became a tool for generating a new image of the President, facilitating a kind of posthumous 'rebranding'. This image breakthrough provided the Law and Justice (PiS) party with the 'added value' of the sympathy of most of the media and the social trust Maria Kaczyńska enjoyed before and after April 10, 2010, in contrast to her husband. The 'double portrait,' multiplied by the press at the time of national mourning, later became an expression of an affirmative approach extended to a defined political circle. It is not surprising then that PiS, which has emphasized the value of 'Lech Kaczyński's testament' and assumed the role of the depositary of his policy, has utilized the photography of the presidential couple (and their biographies) on many occasions.

${ }^{34}$ P. Pawełczyk, op. cit., s. 178.

35 Por. M. Kolczyński, Strategie wysokiego ryzyka - wyborczy rebranding Jarosława Kaczyńskiego, „Studia Politologiczne” 2011, vol. 19, s. 224-244. 
